\title{
Human resources in Serbia - a basic postulate of economic development
}

\section{Development of human resources in Serbia, the labour market and the social price of the transition}

Human resources development is a basic postulate of economic integration and perspectives of the world of labour in Serbia, the restoration and functioning of the labour market and the social price of the transition, as well as being a collective indicator of the success of these processes. These processes can be seen directly in a developmental or technological sphere and in a profitable and competitive national economy within a universal framework. First of all, the labour market is a structural part of the commercial market, along with the goods and capital markets. In other words, it is not possible to establish a commercial market, or the market game as its basic motive force, without a functioning real labour market.

Ultimately, it can be said that activities in the other two markets - the goods and capital markets - indispensably depend on the labour market if we bear in mind that the market game is, essentially, always a game of human capabilities and knowledge. For example, we as buyers decide on some of the offered goods on the market; on a different plane are competing goods or services with their capabilities and qualities. However, if we come to the essence, we can see that the people who have made that product are competing - or, perhaps, it is their creativities, knowledge, professional and technical capacities and their moral values that are competing.

However, the labour market is the most complex, most sensitive and most conflict-influenced part of a market economy. First of all, what is going on in the other two markets - the markets of goods and capital - is not obvious. This is the Adam Smith 'invisible hand of the market'; no matter whether good or bad, it is shown in the markets of goods and capital in its visible form. Likewise, everything that happens in these markets increasingly multiplies, with more difficult consequences. It is clear that the labour market essentially functions on the same principles as the other two markets - the relationship between supply and demand. When supply expands, the price of labour, as in the goods and capital markets, drops and when demand grows, so the price of labour grows also.

But, in that movement of the price of labour there exists one limitation which is specific only in the functioning of the labour market. It comes from the basic and indisputable fact that the subject of the labour force is the human being, or - as it is called in the modern language of economy and sociology - human capital. This means the human being, with its corpus of human freedoms and rights, needs, habits, ways of life, value systems and the family; with all that makes up everyday human life and its purpose. Thereby, it is clear that the labour market is not, nor could it be, just at the junction of the supply and demand relationship, where lives and people's destinies can not be given over exclusively to the blind acting of market regulation. Were it to be otherwise, this would bring into question all the indisputable civilisation 
achievements of the modern age and the quality and dignity of human life and work based on them. ${ }^{1}$

Referring to the differences between the labour market and the goods and capital markets in the hard language of the economy, it can be said that, concerning the dependence of the supply and demand relationship, the prices of goods and capital can, in theory, start from zero. The price of labour, however, can drop (without serious social and political consequences) only as far as is defined by the minimum for survival of the worker and his or her family.

Increased economic and technological development in the modern world, however, has brought supply and rising standards to this plan and, therefore today, instead of survival, more and more is spoken about a civilisation minimum, or the standard level and quality of life achieved by modern civilisation.

This means that the price of labour comprehends a wider circle of needs and requests that are not just based on existence in the narrower biological sense, but which are cultural, civilisational and human - including ones that cannot be expressed by material or financial indicators, or which can barely be so expressed.

Obviously, the functioning of a modern country could not be possible if in the price of labour are not included employees' rights to a general and professional education, to the permanent improvement of their professional and expert skills and knowledge, quality of life, the economic and real accessibility of public services (municipal infra-structure, etc.), the right to a healthy environment and work surroundings, the right to health protection, the right to social security, etc. In that sense, in modern developed societies much is spoken of a social market economy.

Modern practice in that sense certainly confirms that the best results concerning the economic, technological and social development and quality of life of people has been accomplished by those societies which, with their projects of economic and social organisation, have proved that the principles of profitability and economic efficiency are no longer counteracted to social progress but, on the contrary, their optimal connection takes into account a dynamic economic, technological and social improvement. With best practice, these countries have confirmed that social policy, as a factor in the total strategy of economic and social development, is an inevitable factor in the functioning of the labour market.

Furthermore, labour markets can be observed as a confidential, collective indicator of the total state of one country's economy. Namely, each disturbance in the commercial capital and goods markets also influences the overall state of, and relationships in, the labour market. This is expressed by the toughest, most disturbing and the most conflictual social and economic consequences - the growth of unemployment. At the same time, unemployment growth provokes more negative consequences - the reduction of purchasing power within the population which, using the principle of backward force, produces a reaction in the markets of goods and capital, increases the growth of the load on the budget for covering minimal material security for those workers who are left without a job, produces a growth in social conflict and results in social and political instability in the wider economy and in society.

1 Keith Grindt (2002) The sociology of work Polity Press: Cambridge: 158. 
By analysing in this respect the role and functions of a modern state in the economic life of society, it can be observed that significant, and not rarely the largest part, of its measures and activities are directed towards influencing, or regulating, relationships on the labour market. In that sense, state institutions are established, bringing and transmitting measures of active and passive employment policy.

In recent times, the state is faced with limited possibilities for passive employment policy measures (which mostly consist of securing the basic material safety of workers without jobs) and so increasingly is giving more and more attention to active employment policy measures. By this, we mean those measures that:

- comprehend a systematic examination of the cause of unemployment, the social structure of labour and especially the unemployed

- adjust the structure of labour with the needs of the economy and changes in technology and the economic life and structure of society

- adapt educational programmes at all levels to new social, economic and technological needs and requests

- propound and realise the social conditions for the permanent education and constant improvement of the quality of human resources

- assert the sense and development of individual self-responsibility and social responsibility

- educate and train workers without jobs for new employment, for starting their own businesses and, generally, for a more successful confrontation with the challenges of the modern world.

In that regard, it can be said - tell me the condition of your labour market and I will tell you the kind of society in which you are living.

Observing the problems of employment and unemployment in the time in which we live, it can be seen first of all that this is an issue which is present in all countries of the world - developed and those in development; rich and poor; and different by size, number of inhabitants, geographic position and economic and social structure. Therein we can conclude with certainty that employment - apropos its darker side of unemployment - is a global issue. Of course, depending on various factors, this issue is shown in some countries and regions from different sides, at different levels and with different socio-economic and political consequences.

It is logical and was expected that countries in transition were faced with the issues of employment and the operation of the labour market. Furthermore, from the first steps of the transition, employment, jobs and the functioning of the labour market were the biggest challenges and the true indicators of the real success of the political, economic and social reforms in these countries. Besides that, it is necessary to bear in mind a basic aggravatory circumstance - that countries in transition were, at the beginning of this process, for the first time confronted with the question of the establishment and functioning of the labour market and, at the same time, all the difficulties, limitations and negative consequences of the transition were, mostly, reflected in the labour market as an integral indicator of the position of the world of labour.

Serbia, as with many other countries in transition, was also confronted from the first stages with the issue of employment and jobs as a consequence both of the transition and the collective expression of its high social price, with these representing also a pre-condition for the successful conduct of economic, social and total social reforms. ${ }^{2}$ First of all, at the very beginning of the transition process, as in other coun- 
tries, it was clear that the false picture of full employment, which was achieved by unnecessary and unproductive employment that, besides everything else, brought us to systematic economic crisis and the systematic doom of planned economics, had to be brought to an end.

In fact, that is one of the most visible pictures of the false role that the state had in the economic life of our society in those times. ${ }^{3}$ Also definitely stopped was the idyllic dream of absolute, lifelong job security from the simple market-based perspective that new technologies on the one side, and absolute job security on the other, do not go together. That is the shock from which a considerable part of workers have not, even today, recovered. At the same time, it is the one of the main reasons why it is the members of the medium-old and elder generation that are the biggest losers in the transition.

These and the other difficulties with which Serbia and the other countries in transition were faced were multiplied numerously in Serbia given the unfavourable circumstances in which the transition process took place. In Serbia, which was at that time still a part of Yugoslavia, it is clear that the transition was interrupted forcibly by national struggles, division, wars and the break-up of Yugoslavia, and political and economic isolation from the international community.

These retrograde processes left catastrophic consequences for the national economy and the condition and position of the working class, with which Serbia and its population will be battling for a long time. At the same time, it opened the door to the grey economy, the shadow labour market, smuggling and organised crime. All these and other reasons, or obstacles and limitations, made the transition extremely difficult, with conflicts and objectively unfavourable results. It gave for many analysts and researchers a basis from which to define this kind of transition as 'burdensome'.

In favour of this point, besides numerous other arguments in relation to employment conditions and jobs in the previous two decades and today, we can point to the labour market being for almost a decade the subject of ideological manipulation and to the deleterious impact this had on the national economy, especially on the working class, causing huge material, moral and political damage.

Namely, when economic sanctions were initiated against Yugoslavia in 1992, the government in Serbia was faced with a large problem to do with the functioning of companies, where there were broken connections with business partners and the market. It responded, on top of everything else, with developing the category of 'forced vacation'; this was, at least for a while, as long as any other lie could last, the accomplishment of the dream of 'Never-Never Land'. All those who accepted 'voluntary leave on forced vacation' received $80 \%$ of their salary, with all the rights stemming from the working relationship. Without exception, economists, including ones with a strong social democratic orientation, warned that this was irresponsible, insane, that

2 Mihail Arandarenko (2005) 'Elements of employment strategy' collection from Consultation DEB: 'Unemployment in Serbia - problem and alternatives' Economic views Belgrade: 26 .

3 David Dašić (2001) Market economy European University for International Management and Business, Belgrade: 217.

4 Dubravka Stajić (2002) Burdensome transition Institute for political studies, Belgrade: 127. 
nowhere in the world does anyone not working receive their salary and, of course, that this was economically untenable, even for countries that were more developed than Serbia. Many of them gladly and quickly accepted this irrational offer, without thinking how much it would later cost - to each individual and to society in total.

On the other side, one very strong manipulation existed on the part of the government - the fear of losing one's job. This fear-based manipulation proved to be a powerful weapon of the ruling elite in intimidating and disciplining workers and their unions.

Through the fear of job loss, independent citizens and dissatisfied workers, who have often shown their discontent in very radical ways, were transformed, at least for a certain time, into obedient subjects. When we analyse the continuity of this phenomenon, no government, from the beginning of the transition up until now, denied itself the use of this instrument of manipulation. Most often it has been used by starting rumours of dismissals or supplying 'confidential information' concerning those who were on the dismissal list, but always with the rigidly discriminatory practice in which, regardless of real needs, independent and critical union leaders, and others who sought to counteract illegal employer activities, were fired first.

After seven years of democratic changes, Serbia is starting gradually to return to the international political and economic organisations and events, although almost two decades on from the beginning of the transition process, the state of the labour market is significantly unfavourable or, what is worse, the trends are unfavourable.

It is indisputable that all countries in transition have been confronted with the issue of unemployment as the consequence of the necessary property, economic, technological and organisational changes in the economy and society. However, in Serbia it is a question of social endurance, or the immense social, political and economic consequences that unemployment has. In particular, Serbia has, practically from the first steps of the transition, been confronted with massive, long-term, systematic unemployment. Workers were not the only ones affected in companies by unemployment where, owing to privatisation and restructuring, they became economically and technologically surplus; so were young people looking for their first jobs. Out of the total number of unemployed people, the percentage of those who have been looking for a job for more than two years is also extremely high. Searching for the causes of such high, long-term joblessness inevitably takes us towards the total unfavourable flow and effects of economic, social and political reforms in which the social price both reflects and is shown in the highest measure through the incidence of joblessness. Most economists agree on the dimensions of that price.

In that sense, Bude $\geq$ ever considers that the main causes of long-term joblessness in Serbia have been:

- the concept of transition and privatisation

- an over-extended role for tax and a reduced role for productive functions, or a neglect of development in the real sector

- the relationship with the identity and the development of Serbia in the round. ${ }^{5}$

Similar reasons are quoted by other authors. Much research has been conducted into the causes of unemployment, the result of which is that a very rich collection of

5 Bude Šever (2005) 'Causes of unemployment' collection from DEB Council: Unemployment in Serbia - Problems and alternatives DEB: Belgrade, p. 145. 
reasons can be identified which, in the previous period, led to unemployment and which, even today, account for why joblessness is at such a high level. Of course, a very good academic and expert basis for the fortification and implementation of a successful strategy towards the reduction of joblessness, and its gradual bringing into an endurable framework, can be advanced. This would naturally be under the conditions that exist now, and what is called in modern parlance 'political will' or the veritable readiness, responsibility and competency of the ruling political elite seriously to confront itself with this issue.

One of the necessary landmarks in any analysis and on the routemap in the search to resolve issues of joblessness is an insight into the existing structure of employment, or joblessness. In Serbia in 2006, according to data from the Republic Institute for Statistics, ${ }^{6} 2050854$ people were employed. Out of that total, 470714 were private entrepreneurs or people employed in the individual economy or in some other activity. Besides that, according to other sources of data, this number includes a significant number of people who are no more than formally employed, i.e. those without sufficient work scale. The significant number of people who are working in the grey economy and on the shadow labour market, and those who have not registered themselves with the official employment services because they consider that these services can not help them in job search, should be added in here. We need to take account, furthermore, of the totally unfavourable structure of employment, i.e. the incompatibility of the employment structure with employers' needs and labour market demands. In this respect, we can refer to the sectoral breakdown of employment, with $5 \%$ of the total number of employees being employed in the primary sector and $47.5 \%$ each in the secondary and tertiary sectors.

We should add to this unsatisfactory condition of employment and jobs the rapid growth in registered unemployment, i.e. those individuals that have been on the lists of the National Employment Service in the years of transition. The negative inheritance of the previous decade contributes a great deal to these adverse trends where companies realised a surplus of employees and where the abrogation of regulations (especially those on so-called 'forced vacation') is concerned, since these have concealed the real state of joblessness. These adverse trends showed further growth in the first years of the democratic changes. First of all, there has been a growth in total joblessness, following a levelling-off in 2003. Furthermore, we should add in the decidedly weak structural factors: in particular, out of the total number of unemployed people, according to the National Employment Service (NSZ), $61.58 \%$ are professionals. For the most part, this warns of the issue of the incompatibility of the real educational and professional structure of the labour force with economic requirements. It also means the need for a dynamic, systematic and flexible approach to this question, above all through a restoration of the concept and practice of life-long education and training, in terms of a raising of the consciousness in that direction both of the employed and those who are searching for a job.

All this entirely adverse data directs us to a conclusion that one of the necessary steps in analysing the long-term high level of joblessness in Serbia, and defining a strategy for the systematic solving of this, surely one of the biggest political, eco-

6 RZS (2006) Publication on employment in Serbia Belgrade: 11. 
nomic and social problems of Serbia, is obtaining statistical data on the strength, structure and other important characteristics of the existing and potential labour force. Therefore, it is necessary to analyse critically what kind of potential there exists in the human resources currently available to Serbia so that their long-term development could be planned according to the demands of technological, economic and social development. In that sense, it is logical for this process to start with an analysis of the population structure because the population forms the potential from which comes the labour force and, therefore, all the advantages and limitations of the population structure are also directly or indirectly reflected in the structure of the labour force. On this ultimately depends the total economic and technological development of each country.

In this regard, internal data breaking down the labour force into its constituent parts, contained in a Note by the Republic Institute for Statistics, is shown in Figure 1.

Close examination and comparison of the data in the chart indicates that there exists a whole series of unfortunate statistics relating to the population and labour force structure which have a very high economic price that has a knock-on effect on the total population and, above all, on its manufacturing and creative segments. They also represent an obstacle to faster and more efficient economic and social reforms. The primary indicator in that sense is the relationship between the active and the non-active population, which is significantly below the level in economically and technologically developed countries in Europe and the rest of the world.

The unemployed, who are passive during periods of joblessness, should also be added to the non-active population. In this case, the total non-active population rises above $51 \%$ of the total population. There are two basic sources for this situation - an unfavourable age population structure, conditioned by a permanent fall in the birth rate, and the high rate of joblessness. 
Figure 1: Review of the basic population of Serbia by level of economic activity, October 2006 ${ }^{7}$

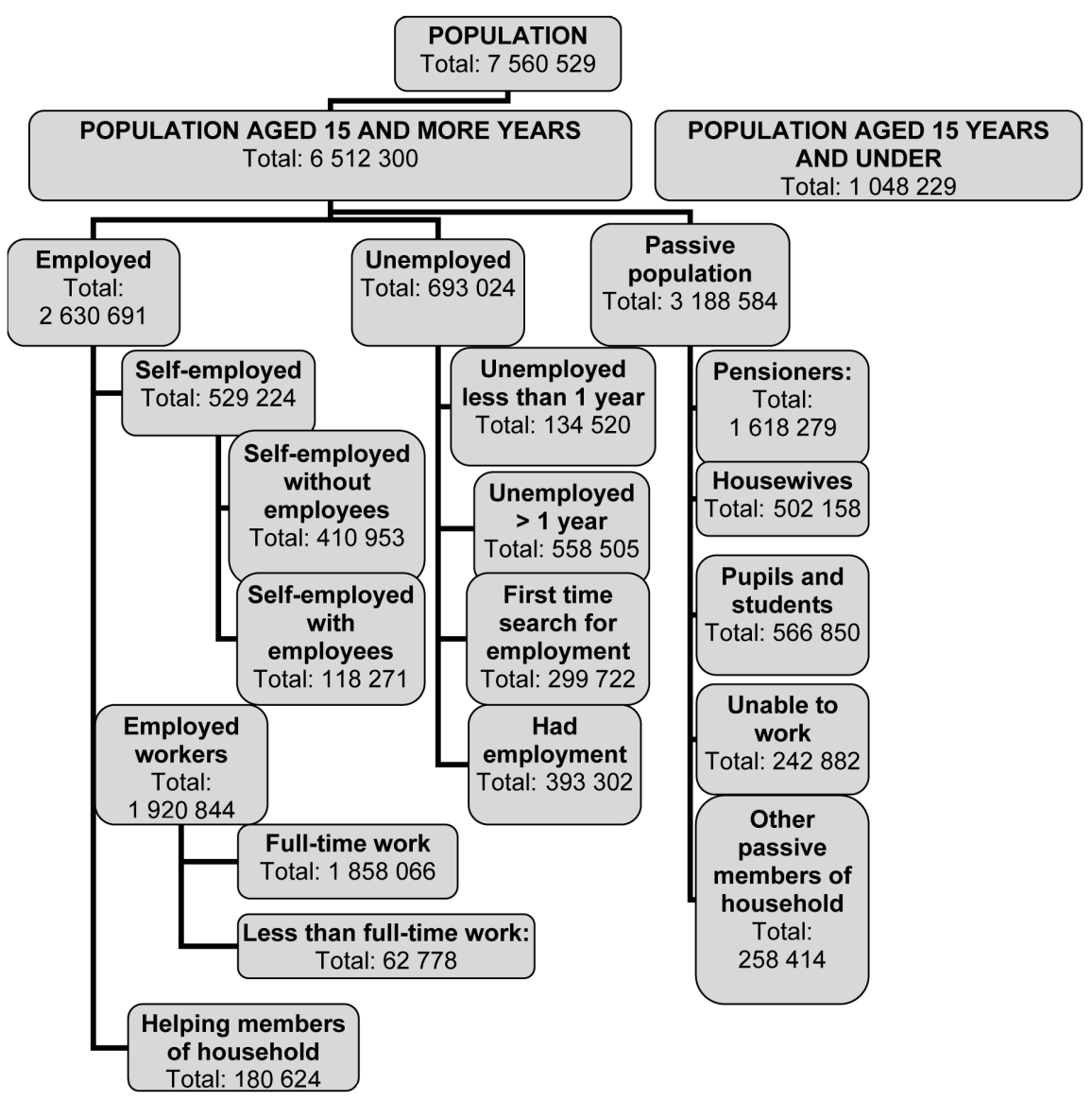

In this context, the extremely large number of pensioners should also be noted. According to these results, today there are 1618270 pensioners in Serbia, which is $61.5 \%$ of the total number of employees. This means that on every employee depends more than two pensioners. That is a burden that even more economically and technologically developed countries could not withstand.

It is obvious that the current generation, members individually of the world of work, is, through its own routine, paying the price for the irrational and tactless moves in the sphere of pensions security by which was bought, many years ago, a false social peace. However, even when the number of employees is being referred to, economists are, all the time, warning about the further present trends of irrational employment,

7 RZS Notice No. 59, Belgrade, 2007, p. 2. 
especially in public services. That represent an additional burden on an already vulnerable national economy.

It is decidedly a disadvantage that Serbia, owing to the effects of this whole series of unfavourable factors, today, almost two decades from the beginning of the transition process, has one of the highest rates of joblessness in Europe, amounting to $26.32 \%$. Furthermore, the situation is especially complicated by the extent of longterm unemployment, the so-called 'systematic joblessness', which is confirmed by data as standing at 693024 of the total number of the unemployed. 558505 of them, or $80.53 \%$, have been unemployed for more than one year. Among this number are those who are looking for employment for the first time, and this means we are referring to young people who have just finished schooling, of whom we can count 299722 people, or $43.21 \%$. Within this data is, of course, one part of the answer to the question about the intensive 'brain drain' with which Serbia has been faced in previous years.

However, within the framework of this unfavourable data, we should isolate one positive statistic - the high number of self-employed, amounting to 529224, or $20.11 \%$. This indicates that more and more people, besides the numerous problems and limitations that, by a distance, can be attributed to inadequate state policies, are succeeding in finding the source of their existence in founding their own businesses.

Besides the whole series of factors that, in prior years in the transition, have had an adverse impact on economic flows in Serbia and, in that framework, on employment, we can extract in particular a disadvantageous education population structure in total and amongst employees. Many of the data in Table 1 refer to aspects of this issue:

Table 1 - Population aged over 15 years by education achievement ${ }^{8}$

\begin{tabular}{|l|c|c|c|c|}
\hline Republic of Serbia & Total & Employed & Unemployed & $\begin{array}{c}\text { Passive } \\
\text { population }\end{array}$ \\
\hline Total & 6512300 & 2630691 & 693024 & 3188583 \\
\hline Without schooling & 263509 & $(30866)$ & $(4601)$ & 228043 \\
\hline $\begin{array}{l}\text { Incompleted elementary } \\
\text { school }\end{array}$ & 783014 & 176899 & $(14879)$ & 591236 \\
\hline Elementary school & 1554618 & 456539 & 131859 & 966220 \\
\hline High school & 3136789 & 1506376 & 480920 & 1149492 \\
\hline Higher school & 336994 & 180026 & $(31974)$ & 125021 \\
\hline Faculty, academy or university & 437376 & 279985 & $(28820)$ & 128571 \\
\hline
\end{tabular}

Source: Republic Institute for Statistics, Belgrade, 2006.

8 ibid, p. 13. 
As could be expected, the worst aspects lies in the education structure of the passive population. The biggest problem is that it is not realistic to expect that this kind of passive population may, in some shorter time period, be included in the working process in more demanding working and manufacturing practices, so as to reduce the gap between the active and the passive population.

It is also obvious that, among unemployed people, those with a high school education predominate, amounting to $69.43 \%$ of the total number of the unemployed. This data should be observed in connection with the figures on the large number of individuals who are looking for a job for the first time and, in addition to that, those who have been waiting for one for longer than one year. On top of the causes of this situation which have already been mentioned, this figure mostly warns us as to the longpresent gap between the concept and the structure of the education system, or the structure of knowledge gained during the schooling process. Of course, there is no need to prove separately how this situation adversely influences the total condition of, and relationships on, the labour market.

In the same way, the education structure of the employed, as one of the images in the total picture of the nation's education, is far from satisfactory. In this respect, we can refer to the total number of employed in Serbia, of which more than $25 \%$ has only an elementary school education, while one-third of the group that attended elementary school (but no more) did not even finish it. With regard to this large group of employees, specialist experts often use the term 'functionally illiterate', which refers to the deep gap between the requirements of a general working culture (and professional and expert skills and knowledge), which increasingly imposes new technologies and new social circumstances, and the very limited working and professional capacities of those called upon to undertake it. There are very few, or almost no, possibilities for them to be actively included in the process of 'lifelong learning'.

At the same time, it can not be marked as satisfactory that the percentage of employees with at least a faculty education is $10.63 \%$. If we add on top the notion that the cadre of those with high education is predominantly, or even exclusively, centred in Belgrade and some other big towns in Serbia, then, without a radical change in policies in these areas, we can not expect the better regional development of Serbia.

These and other limited circumstances influence the position that obstacles are being removed only very slowly, and scarcely to the higher successfulness of economic and social reforms. This reflects especially negatively on employment and jobs and it can be seen in that some negative trends in these areas are still present. The following data in Table 2 refer:

Table 2 - Rate of economic activity, employment, unemployment and inactivity for the population aged 15 and over, October $2006^{9}$

\begin{tabular}{|l|c|c|c|c|c|c|c|c|}
\hline Years of age & \multicolumn{2}{|c|}{ Activity rate } & \multicolumn{2}{c|}{$\begin{array}{c}\text { Rate of } \\
\text { employment }\end{array}$} & \multicolumn{2}{c|}{$\begin{array}{c}\text { Rate of un- } \\
\text { employment }\end{array}$} & \multicolumn{2}{c|}{$\begin{array}{c}\text { Rate of } \\
\text { inactivity }\end{array}$} \\
\hline & $\mathbf{2 0 0 5}$ & $\mathbf{2 0 0 6}$ & $\mathbf{2 0 0 5}$ & $\mathbf{2 0 0 6}$ & $\mathbf{2 0 0 5}$ & $\mathbf{2 0 0 6}$ & $\mathbf{2 0 0 5}$ & $\mathbf{2 0 0 6}$ \\
\hline $15+$ & 53.5 & 21.0 & 42.3 & 40.4 & 20.8 & 20.9 & 46.5 & 49.0 \\
\hline $15-24$ & 35.8 & 37.4 & 18.7 & 19.5 & 47.7 & 47.8 & 64.2 & 62.6 \\
\hline
\end{tabular}




\begin{tabular}{|l|c|c|c|c|c|c|c|c|}
\hline Years of age & \multicolumn{2}{|c|}{ Activity rate } & \multicolumn{2}{c|}{$\begin{array}{c}\text { Rate of } \\
\text { employment }\end{array}$} & \multicolumn{2}{c|}{$\begin{array}{c}\text { Rate of un- } \\
\text { employment }\end{array}$} & \multicolumn{2}{c|}{$\begin{array}{c}\text { Rate of } \\
\text { inactivity }\end{array}$} \\
\hline & $\mathbf{2 0 0 5}$ & $\mathbf{2 0 0 6}$ & $\mathbf{2 0 0 5}$ & $\mathbf{2 0 0 6}$ & $\mathbf{2 0 0 5}$ & $\mathbf{2 0 0 6}$ & $\mathbf{2 0 0 5}$ & $\mathbf{2 0 0 6}$ \\
\hline $25-34$ & 82.3 & 80.5 & 59.0 & 59.4 & 28.4 & 26.1 & 17.7 & 19.5 \\
\hline $25-54$ & 81.9 & 80.3 & 65.6 & 64.6 & 20.0 & 19.6 & 18.0 & 19.6 \\
\hline $35-54$ & 39.5 & 36.1 & 68.6 & 66.9 & 16.3 & 16.8 & 18.1 & 19.7 \\
\hline $55-64$ & 11.4 & 7.9 & 35.4 & 32.6 & 10.3 & 9.5 & 60.5 & 63.9 \\
\hline $65+$ & 11.4 & 7.9 & 11.3 & 7.8 & 0.7 & 1.0 & 88.6 & 92.1 \\
\hline Overall activity & 65.2 & 63.6 & 51.0 & 49.9 & 21.8 & 21.6 & 34.8 & 36.4 \\
\hline
\end{tabular}

Source: Republic Institute for Statistics, Belgrade, 2006.

First of all, the planned drop in the activity rate in 2006 in comparison with the figure for 2005 is notable, especially for the most numerous age group, including those who are at the most productive part of their working life. It is clear that there is no expected growth in investment and economic activity, primarily in those activities that can employ numerous workers in the 25-54 age group, where the activity rate in 2006 is expected to be $64.6 \%$ compared to $65.6 \%$ in 2005 , and in the 55-64 age group, where the rate is expected to be $32.6 \%$ compared to $35.4 \%$. On balance, there is no expected growth in employment which is, on the one side, the indicator of the successfulness of economic and social reforms and, at the same time, a condition for stable economic growth.

But, the key obstacle to a faster resolution of the unemployment issue is the insufficiently dynamic scale of economic activity that, in many cases, is not enough even to cover expenditure on a momentarily-employed labour force. In this connection, we can look at data on employers' searches for new workers. In previous years, employers' needs for new workers were, on average, at between around 40000 and 45000 workers; on an annual basis, around 500000 workers. Of this number, around $70 \%$ of demand was for professional workers with the remaining $30 \%$ for manual labour. However, this number does not offer a real picture of labour force demand, because it includes jobs announced more than once, re-employments, student placements, shortterm fluctuations, workers swapping jobs for a certain period, and so on. When in this way we come to realistic data on the actual demand for workers in practice, one conclusion is imposed - actual demand for labour frequently does not cover even replacements for the employee drain. ${ }^{10}$

In total, most analysts agree that the labour market, seven years after the beginning (or recommencement) of political, economic and social reforms after more than one decade of forcibly postponed transition, is characterised by several predominantly unfavourable characteristics. These are, primarily:

9 ibid, p. 15.

10 Jugoslav Mijatović (2005) "Joblessness problems in Serbia in the period of transition and possibilities for solving them' Economy views DEB: Belgrade, II, p. 63. 
- slow economic growth that limits the possibilities of jobs for those groups of people who are without a job, including those working in the 'grey zone'

- unsatisfactory total employment regarding the number of inhabitants and the active population

- unfavourable structure of employees in all sectors (primary, secondary, third)

- a very high rate of open (registered) unemployment

- an unfavourable joblessness structure in terms of age and skills

- long wait for employment

- major levels of joblessness (employment surplus)

- relatively weak movement of the labour force (labour force market inflexibility)

- high employment in the grey economy.

When we consider all these economic and social consequences, and others besides, of the high joblessness with which Serbia has been faced for almost two decades, it is clear that joblessness is one of the key factors in industrial and social conflict and the instability of political society. Therefore, the fight against joblessness has to be one of the priorities not only of the political government but of unions too, as well as employers and all other relevant social actors.

The first step in this direction is to confront the complexity of this issue and its connection with almost all other aspects of the economic, technological and social development of society.

In that sense, the many authors who have said that employment and jobs is, in essence, another name for a decent selective strategy for the technological and socioeconomic development of society are right.

In spite of having been insufficient, the attention of the academic and professional public towards questions of employment opportunities has expanded. A considerable number of analyses and research studies from this sphere have presented numerous but partial and rarely systemised measures for resolving the joblessness issue. Most of the systematic approaches that have been developed have one mutual denominator one which necessarily observes employment and jobs as an integral part of an all-encompassing strategy for the development of society.

Foundations for such an approach have been made and the National strategy in the fight against poverty sets out that the fight against poverty and long-term high joblessness are two sides of the same process. ${ }^{11}$ This strategy comprehends three basic targets - acquisition of tenable growth and development; protection against the repeated experience of transition losses; and the inclusion of vulnerable social groups in economic and social processes and activities at the widest level of society.

In that sense, Mihail Arandarenko articulates that Serbia, as the poor European country, has two key orientations in the context of strategic reform that are mutually complementary - European integration; and the fight against poverty. Accomplishment of these two associated targets implicates the establishment and development of a modern market economy that encompasses the principles of social justice and solidarity and provides for the participation of the poor and other vulnerable sociable groups. In that direction, Arandarenko identifies three target groups in terms of their key significance for a strategy on jobs:

11 National strategy in the fight against poverty Document of the Government of the Republic of Serbia, Belgrade, 2003, p. 2. 
- attraction of foreign direct investment in the name of the expansion of employment

- achieving a social pact between the political powers, unions and employers for an acceptable strategy on jobs for all social partners

- a regional approach to resolving the unemployment issue. ${ }^{12}$

It is obvious, however, that the implementation of each of these requirements is conditioned by the total flow and the results of the political and social reforms by which will be achieved legal security and political and social stability, as well as stable and dynamic economic growth.

The question of the successfulness of the transition process, i.e. its economic and social reforms, can be observed through the perspective of the capacities of human resources. The process of the transition in all countries has its political, economic, social and moral price. Owing to the influence of the well-known disadvantageous circumstances, the price of the transition in Serbia is extremely high and, in essence, has already for a long time been beneath the lower limits of social endurance and human life, dignity and work for most of the population. All these aspects of the price of the transition are collected in one result - the condition of human resources. This is manifested through the dormancy of available human potential; through a lack of motivation towards work, expert and professional education and improvement; obstruction of work - go slows; the loss of hope; etc.

In addition, it is a powerful source of industrial and social conflict and social and political instability in society. This means that a significant part of available human creative possibilities, instead of being put to economic and technological development, is spent irrationally and in side-show conflict.

All these phenomena - issues that, often invisibly, concern employment - are tightly connected with limitations in the development and use of human resources that, ultimately, are evinced through the huge, and high, economic price that an impoverished society and a destroyed economy has to pay.

In this way, a generic spellbound relationship circle is essentially spelled out in the long-term: human resources $\rightarrow$ failure of economic and social reforms $\rightarrow$ human resources. Leaving this spellbound circle may be made in the same place where the circle has its origin - in human resources, i.e. in removing the numerous limitations and obstacles to their development and their full and appropriate use. It can not be done by economic theory by itself, but it can contribute very much and only within the framework of one expedient, systematic, interdisciplinary approach.

In that sense, it is necessary to deliver the conditions for the development of individuals as follows:

- provide for their improvement

- regulate internally within firms the obligation of improvement discharge or downgrade, or retire, those who do not accept improvement. ${ }^{13}$

12 Mihail Arandarenko (2005), op. cit: 92.

13 Edita Kastratović (2008): Even regional development and MSP Sector in Serbia International Higher School for Entrepreneurs: Belgrade. 


\section{Grey economy and the shadow labour market}

The grey economy, the opaque economy, the shadow labour market - just a part of the rich language which signifies one of the most significant developments of the modern age. In the light of history and current practice, the grey economy, in the sense being debated about today, is a phenomenon of the new age whose foundations are otherwise represented by the rule of law, the market economy and multi-party parliamentary democracy.

The grey economy is the other side of the market game, or one of the aspects of the market game, that is played in unfavourable formal-legal conditions regarding the regular definitions of the game and its protection by legal norms.

Regardless of policies and economic organisation type, the political forces in power, the development and efficiency of the legal system or the level of economic development, there is no modern society in which the grey economy and a shadow market for goods, capital or labour are not present. The level of representation of the grey economy and the shadow market present a definitive indicator of the level of development of the economy, as well as of social and political society. Speaking in the language of mathematics, the level of representation of the grey economy and the shadow market is in inverse proportion to the degree of economic development, democracy and the efficient functioning of democratic and legal institutions, social security and social justice.

The grey economy and its inevitable companion - the shadow market - shows strong resistance and a capability for adaptation and survival in different social circumstances. Numerous social and economic theories, depending on the political, economic and moral perspectives of their authors, and from the social circumstances in which they were developed, explain this phenomenon in different ways. Analysing the grey economy from the perspective of the process of globalisation, it can be said that today it presents as an inevitable and structural part of the globalisation process. Furthermore, if globalisation is defined as an inevitable process of the more dynamic and stronger economic, political, cultural and social connections of the modern world, we can ask the question of whether the grey economy speeds up or inhibits these processes.

The history of the grey economy as a modern practice decidedly confirms that there exists a high degree of independence between economic agents, poverty and the grey economy. They also indicate the following points:

- the grey economy is present in all parts of the world, in all types of political and economic organisation, as much as in different levels of development of national economies, thus giving the foundation for the conclusion that the grey economy is today a global phenomenon, since it is extremely adaptable to different local circumstances

- the presence in the national-legal economy differs from country to country, by a factor of even three to four times, and that each country has its limit of tolerance towards the different phenomenal shapes of the grey economy and the shadow labour market

- the presence of the grey economy in countries in transition, as could be expected, is several times higher than its presence in developed, democratic countries with market economies; in some of these countries, the grey economy presents a domi- 
nant aspect of the national economy, meaning that an open and even market game exists in adverse proportion in relation to the grey economy.

Concerning the weight of this issue and its economic and social consequences, we can refer to the Report of inquiry about the grey economy, produced in December 2000 by the Economic Institute from Belgrade. In that report, it is indicated that at least one million people were engaged in the grey sector and, if we add to this number the category of self-employed who are working on the streets, in houses and in other places without a registered company, then the total number of participants in the grey economy comes close to 1200000 individuals, creating 35\% of additional social product that are not comprehended by official statistics and settlements. On the other hand, research studies by the Labour Market Institute have shown that some 617000 people work in the grey economy.

In both cases, however, it is shown that more than half of the participants in the grey economy are really or fictitiously employed in the regular sector, while the rest are pensioners, students and refugees. In this, Serbia is fundamentally different from other countries in transition and from other market economies where it is mostly the unemployed who are in the grey economy.

\section{The grey economy and other frontier areas of economic life}

In considering the grey economy, it is necessary to bear in mind that it is a phenomenon that is extremely adaptable to different social circumstances, that it is very flexible and rapidly engages in the context of changed social circumstances. In this respect, if we compare the grey economy with the formal, then unquestionably the grey economy, in regard to flexibility and adjustment to changed social circumstances, has an absolute advantage.

Besides everything else, we need also to be concerned with how the grey economy presents itself in numerous numbers of different manifestations; that these manifestations may change relatively quickly, or concede their place to new forms; and, additionally, how these manifestations are researched and classified.

In defining the grey economy and its relationship with other associated phenomena, it is very important to note that the grey economy never appears by itself - or, rather, it can not appear or exist on its own; its inevitable followers are worse. These are the shadow market, including the shadow labour market, and its most radical and socially most dangerous form - the human trade - and different forms of criminal activity in which a central position is held by organised crime. This represents the largest source of issues and bad outcomes that indisputably produce the grey economy. If we refer to it beyond this context, the grey economy looks like a forced source of existence for marginalised social groups. Vice versa, in this context can be seen the real dimension and consequences of the problem.

For a clear separation of the grey economy and the accompanying associated phenomena, it is necessary to take into consideration those criteria which are essentially significant. According to these criteria, the phenomena in this field can be classified in the following groups:

- businesses that are in direct confrontation with the law, and in which performance represents the exercise of criminal activities directly within the criminal sphere: being acts connected with the people trade, especially children; prostitution; por- 
nography; the drugs trade; the illegal trade in alcoholic drinks, tobacco, oil and petroleum-derived products; etc

- businesses that are partly illegal and partly legal, i.e. where the legal part of the business is used in some way as a mask for illegal business

- businesses that are essentially legal or which, with small corrections in the law and economic system, can be installed within legal economic flows

- businesses that are formally legal under the law but which, in essence, present a logistical base for grey economy flows and the shadow labour market

- businesses that are legal but where the employer, with the spoken or unspoken support of political forces, actually holds employees outside the law in the zone of the grey economy (non-registered workers, without pensions and health insurance and without any work, economic, social and union rights).

These groups of businesses, as a rule, do not appear one by one but are always connected and conditioned, i.e. are shown as parts - in such terms - of one parallel business chain.

In the economic sense, these business types function as relatively individual economic, business sub-systems. In the social sense, those working in the grey economy and associated fields present specific social groups with different interests, moral and social attitudes and principles and, therefore, to a significant extent we can speak of parallel systems. If, based on this kind of approach, we draw a partition, we could say that there are two sub-systems in foundation - one formal, official, where there are places for a certain number of people; and the other informal, unofficial, where the key basis is the grey economy and its associated phenomena and which accommodates all those who can not find their place in the first. ${ }^{14}$

Our society, unfortunately, belongs among those where the sub-system, and the way of life and destiny of a large part of the population, is based on the grey economy and its associated phenomena.

This is one of the strongest sources of social conflicts and conflicts in modern Serb society. The strength and very negative consequences of these conflicts lie in that, in essence, two different Serbias are in confrontation here - the Serbia that lives within the existing formal economic system and the Serbia that lives on the basis of the grey economy and its associated phenomena. The conflict between these two Serbias is strong and provokes even bigger consequences in numerous political and other social conflicts.

\section{How to recognise and identify sources of the grey economy in Serbia}

Towards an appreciation of the essence of the grey economy and its political, economic, social and moral consequences, we should first concentrate on its causes, or the sources of its origins. This question can be asked in a different way - how can we recognise and define the key footholds of the grey economy. This is most important since the key footholds of the grey economy are, at the same time, also the key footholds of its associated phenomena. All research studies, as other data sources un-

14 Petar Dukić (2006) 'The organised world of labour in Serbia today: between economic reforms and populism' South-East Europe Review for Labour and Social Affairs 9(4): 20. 
doubtedly confirm, point to the source of the grey economy as lying within the political power, i.e. the way in which society is managed.

The numerous and varied sources of the grey economy can basically be classified into the following basic groups:

- those from the economic and political system

- those from local and regional specifics

- those from tradition, culture, the way of life; i.e. the historical inheritance as a whole

- those connected to people's personal destiny; i.e. their individual qualities and value systems.

\section{Sources that result from the economic and political system}

Within this group of sources of the grey economy, three sub-groups should be analysed in particular:

- legal system

- political system

- economic system and measures of economic policy.

It is clear that the organisational concept of all these three sub-systems depends on the interests and orientations of those political forces that are at that moment in power, or, as it is said in modern political parlance - on the political will of the ruling elite.

In other words, the partial and imperfect sub-systems that represent in our society the basis for the grey economy are not just the result of ignorance, inexperience and objective limitations, but a lack of a political will amongst the ruling elite to make the system more qualitatively and economically efficient.

In contrast, it is necessary to create a becoming macroeconomic environment if we are to have an equal market game.

This open perspective of a conflict of interest between the ruling elite and essential society has been strongly expressed from the beginnings of the transition process and today represents one of the biggest obstacles to successful social reforms.

The source of this conflict and of the whole complex of systematic sources of the grey economy has its roots in the unlimited state power of the previous single party system which, in great measure, are present in the prevailing social circumstances. It can be mirrored in the significant policy dominance in all areas and spheres of social life and, in fact, in the key area of policies of social promotion.

Truthfully speaking, in the first phase of transition where Serbia objectively now is (bearing in mind that the transition in Serbia was forcibly interrupted for more than one decade), the state now has all the levers of power in its hands and, therefore, objectively holds the biggest responsibility for the flow and outcome of this first phase of transition.

However, a successful flow of reform considers that the state, or the political power, should gradually transfer its authorisations to the democratic institutions and organisations of civil society; thus is created a balance in the distribution of social power characteristic of the economies of developed democratic societies of the mar- 
ket economy. This process in modern Serb society is flowing extremely slowly, accompanied by strong resistance from the advantaged social classes whose privileged positions are established in an unlimited way, which implies also unlimited state power.

\section{Sources that result from local and regional specifics}

This group of sources of the grey economy has its own basic foothold in an advanced collection of sources. However, the specifics of this group is connected with particular cultures and the traditional, economic and geographic distinctions of certain local communities or regions. It is clear that, regarding the development, forms and subjects of the grey economy, a coterminous domain, for example, is of great importance or, otherwise, a domain where specific product types are produced.

Likewise, within a local community, specific local actors in the web of the grey economy and its associated phenomena very often create some type of sub-systems within the grey economy. For example, it is known that some cities are characterised by a developed trade in used cars and car accessories, and others by trade in other products, and, therefore, a map of the grey economy, shadow market and other associated phenomena can be created. Moreover, such a mapping process represents a necessary instrument in making an efficient realisation of strategy in the fight against the grey economy.

Sources that result from tradition, culture, the way of life; i.e. the historical inheritance as a whole

The grey economy, and a great measure of deeply-held attitudes towards it, is inherited from the previous single party system based on social property. In that system, private property and entrepreneurs were referred to as an exception, as an accident, and tax was a far more ideological and political, than legal and economic, question: systems of tax collection and (re-)distribution were mostly dependent on the political power.

In this system, that is in the real life of society, numerous forms of the grey economy were certainly present and were commonly accepted (for example car and domestic apparatus repair, various types of services, vocational work), while it was considered that these should not be legalised and taxes paid on them. Of course, in that way the country was able to buy a false social peace, but it has left a legacy after the destruction of the single party system.

\section{Sources connected with individual qualities and value systems}

This group of sources of the grey economy has been tested least of all but which have an exceptional, dominant significance in transition processes in several ways. This comes from everything in such processes, but especially the major social changes, inevitably running right through people's personal destinies and their individual and collective psychological perceptions of all that is going on.

A majority of the working population was, and still is, exposed to the real possibility or fear of the loss of their employment. That shock is bigger if we bear in mind that an important element of the inheritance from the previous system - absolute job security - that can not survive in the market economy. 
That fear, often, became the subject of political and ideological manipulation. If, therefore, we bear in mind that the fear of losing one's job is one of the greatest fears of modern civilisation, then it is clear that such an eventuality will leave visible tracks on the individual and collective psychological plan. ${ }^{15}$

\section{Elements of strategy in the fight against the grey economy}

The market economy experiences of developed countries and leading countries in the transition that have successfully confronted the grey economy, i.e. succeeded in essentially reducing or marginalising it, confirms that one of the preconditions for successfully fighting the grey economy is that the fight itself and all forms of social activities should be made public in a plan. In this way, the sense of its destructive consequences for the whole of society can be systematically, organisationally and permanently built.

In this regard, we should in particular critically view and examine the oft-present assertion that the grey economy, with all its indisputable negative consequences, is nonetheless useful since it employs people and brings a solution to current economic issues in society.

It is clear that the grey economy partially mitigates actual economic issues in society, especially unemployment, small earnings and the low purchasing powers of the population. However, if the grey economy and its association with secondary phenomena, above all the shadow market and organised crime, are analysed strategically, in the long-term, then it can be proved that it produces extensively more damage not only to the economic situation but across the whole social plane.

The grey economy and its associated secondary phenomena grew out of the destroyed social structure of the previous system, demolishing and preventing the reconstruction of the foundations of all modern, developed democratic societies - the middle class.

That space in the case of Serbia is being taken by those who are engaged with the grey economy and its associated phenomena, building a parallel system against all those who belong to the formal, regular system. Of course, those who are working in the grey economy, especially those for whom this is the only source of earnings, are automatically excluded from the possibility of accomplishing any working, social or union rights while the basic human rights for this group are often reduced or imperilled.

All these issues provide the basis for a question as to whether it is at all possible, and then under what conditions, for a wider social strategy to be constructed around the fight against corruption. Actual conditions in society, especially in the field of the grey economy, clearly show that such a strategy has not been put together and, furthermore, that serious, systematic attempts to do so have not even been made. At the same time, it is obvious that, without creating such a strategy, the permanent, systematic, efficient fight against the grey economy and its associated phenomena is not possible.

15 Zlatko Šram (2006) 'Social attitudes and individual qualities as political culture components' in the collection Five years of transition in Serbia Friedrich-Ebert-Stiftung, SD Club: Belgrade: 201. 
Therefore, as a first step, it is necessary to define key social actors who have the interests and capacities individually and collectively to be included in the fight against the grey economy. Logically, that set of interests should encompass:

- political powers

- employers and employer organisations

- unions

- those employed in the regular sector

- those employed in the grey economy

- domestic and foreign investors

- political parties that pretend to receive, and permanently hold, the support of the electorate.

This list of actors alerts us to the major possibility that among them there exist different approaches towards and relationships with the grey economy, as well as concerning the methods and means of the fight against it. That approach is conditioned with different positions, the different social power of individual actors and the different level of direct or indirect inclusiveness, some of which lies in the grey economy itself.

In this regard, building and realising a strategy for the fight against the grey economy is confronted with a basic obstacle - achieving a basic consensus on the strategy between all the actors. It also considers that each actor individually has already recognised that it is in his or her own interest to fight against the grey economy.

A successful national strategy in the fight against the grey economy and the shadow labour market entails respect for one elementary fact - that the grey economy is one of the most important aspects of discrimination - political, economic, social and human. The keys to that discrimination are held in its own hands by the political government - its bringing some into a privileged position and others into a poorer starting position were as if it had demolished the basic principle of the market game, as a key indicator of economic and technologic development in society. It can be concluded, in other words, that the formal and the informal economy are connected by a unique principle. ${ }^{16}$

\section{New management principles in industrial relations in Serbia - condition and perspectives}

Examining the situation of industrial relations in Serbia, it can be said that Serb society still gives an impression of a dominant conflict society, which is otherwise characteristic of societies at the beginning of the transition process.

The reason for this lies in that the transition in Serbia can be characterised as expressively difficult and expensive in terms of its social consequences and that, in many respects, Serb society does indeed reside at the beginning of the transition process.

16 V. Franićević and I. Bićanić (2003) 'The poor, excluded and transitional losers in southeast European countries: Explaining the paradox' draft paper for the International Conference on Inequality, poverty and social expansion in south-east Europe Friedrich-EbertStiftung: Belgrade, p. 27. 
Strikes are a part of everyday Serb life. Besides that, none of the organisations (employer associations, unions, state organs) has any systematic statistics on strike trends and their characteristics, which is a big restriction on academic-research work in that area; nevertheless, informal sources indicate that, in Serbia there are daily, on average, around fifty strikes.

Often these strikes appear by a degree of radicalism and take the form of a classical strike, or are otherwise combined with other radical protests such as public protests, blocking of deliveries, battles with factory security, blockading of transport routes, and so on. This means that daily in Serbia there exists fifty points of neuralgia, i.e. potential sources of social and industrial conflicts in their wider dimensions. A boundless amount of energy is spent in these conflicts, which also slows down the process of economic and social reforms.

Reasons why workers start a strike are different - low wages; delay for a number of months in their payment; illegal privatisations whose price is being paid exclusively by employees; the violation of the human, economic and social rights of employees; etc. It is distinctive that, however, among the reasons for the large strike rate, higher than in others, is that, in successful transition countries, strikes of a political nature are present. The reason for this is that, in Serbia, in the conditions of a slackened transition, many questions which are mostly of a political nature have still not yet been resolved. At the same time, experience has taught strikers that the resolution of their daily, revanchist requests, above all for decent earnings and employment security, are not possible without a prior solution to these strategic questions. ${ }^{17}$

The question of the lawful regulation of the right to strike is still an open one. Numerous theoretical and practical divisions and separations are present in the existing plans, in which unions are insisting on a special and detailed strike law.

It is partly an attempt of the divided and confronted unions on the union scene of Serbia, with regard to their defects and limitations as demonstrated in the little social power that they wield, to seek cover behind the law. The experiences of other countries that have passed these types of temptations in previous decades, confirm that something like this is not possible: it is necessary to establish an optimal relationship between autonomous regulation (collective negotiations, social dialogue) and the law.

Finally, it is true that the effects of strikes in total are small and that they are on a trend of further decline. This is conditioned in general by the unfavourable economic situation in society, the weaknesses and divisions inside the union movement and an inadequate strike strategy.

Strikes also undermine the already low economic strength and capacities in society, warning all three social partners - country, employers and unions - to find the exit route by giving the advantage to the development and usage of appropriate instruments to establish the social peace.

It is, primarily, a question of responsibility and the real capacities of all three social partners that, on the principles of mutual trust and corporate advantage, can be built the mechanisms and practices of social peace. In this regard, actual practice documents an unfavourable situation amongst all three social partners. This is especially visible, however, when we talk about unions.

17 Srećko Mihajlović, Zoran Stojiljković and Gradimir Ivanić (2004) Union in changes changes in union UGS Nezavisnost and Progetto Sviluppo, CGIL: Belgrade, p. 36. 
Namely, in Serbia today, almost two decades after the beginning of the transition, we can speak about a union movement in the real sense of the word. Serbia has, however, a disintegrated, divided and confronted union scene, against which background there does not exist even a minimum of mutual co-operation in defence of interests and union solidarity. From the first steps of a union movement, mutual co-operation is one of the key sources of union strength but, on the contrary, unions are confronted between themselves, act as enemies and frequently work openly against each other.

Of course, such a condition and relationships between unions have ruinous consequences for social power, which is remotely lower than the demands put before unions in the modern age and social circumstances in Serbia. In other words, it is one of the key reasons why unions are on the margins of social events. ${ }^{18}$ Conditions and relationships on the union scene can be analysed in total and understood in the right way only in the context of wider social developments. During this time, Serb society has been a predominantly conflict-ridden society, faced with the most radical and most ruinous aspects of social divisions and conflicts - nationalism and war.

Even today, Serb society belongs among the unsuccessful countries in transition that have not been able to build a minimum social consensus on the routemap for and social price of economic and social reforms and the distribution of this price across all social levels. Therefore, everyday industrial and social conflicts have become a part of everyday life in modern Serbia on which people uselessly expend their considerable social energy. Unions have not only not succeeded in confronting these separations, but they have also become both their component and their victim. Namely, a society in which where there does not exist a minimum generally-accepted development strategy can not be expected to define even a minimum mutual strategy amongst unions. In this way, unions are actors in, and victims of, one unfavourable social state which Serb society has held for almost two decades in a spellbound circle of economic, social and political crisis. Above all, what must be faced is that the union scene in Serbia is decidedly crushed and atomised, with the characteristic of giving advantage to partial union interests in companies and local communities. Consequently, this has unquestionably contributed to unfavourable solutions both in workplace and in union legislation.

However, the main problem lies in a failure of capacity and a lack of readiness of union leaderships to join in constructing a democratic union infrastructure, by which we mean an internally democratic organisation and way of working, as well as setting a public face for unions.

Distinctive in this respect is that all unions, and therefore those formed at the time of the establishment of union and political pluralism, have some of the foundations of union organisation from the period of the single party system, thus ironically following the one union of those times. This is, above all, the so-called 'basic organisation of unions in the company or institution', with an expressively high degree of autonomy concerning primary decision-making powers that are often not in accordance with positions and union policy at a higher level, as well as the distribution of a larger part of union membership. 
That type of concept and practice leads toward their feudalisation and essentially reduces union social power. With this is connected the issue of inopportune spending on the union membership, including here those efforts of an objectively very limited range to cover a social function with regard to the situation of union members, that is, the poverty of most members of the world of labour.

The atomisation of the union scene in Serbia is reflected in the already-mentioned presence of more than 15000 basic union organisations and the existence of three union confederations - the Serb Federation of Independent Unions; UGS Nezavisnost and the Association of Free and Independent Unions - and a number of so-called 'home unions', firstly in large public companies, such as the Union of Electricity Workers in Serbia, Union PTT, and Union of the Oil Industry of Serbia. We should also add here the several new initiatives for connecting unions in similar activities, such as the confederations of independent unions which gather unions in public companies that are just in the process of reconstruction and privatisation.

On its own, the existence of a large number of union organisations on different levels is, on one plane, a visible indicator of the atomisation of the union scene and the divisions and conflicts between its actors. However, the process of becoming isolated, the path of organisation and the work of the various unions also represents in essence a movement which is operating in a spellbound circle of impotence.

Most of these unions came out of unaccomplished leader ambitions, out of the requests of political government or political parties, or out of discontent over the work of earlier unions. Furthermore, new unions, as a rule, present themselves as less or more successful copies of the unions out of which they grew.

The over-production of new trade unions describes the growth of their impotence, i.e. their further marginalisation. Many times have been present the phenomenon of ruthless members sacking one union for another. This process confirms the long-time present and every day more expressed trends of reducing the degree of union organisation (the number of union-organised workers in all unions as a percentage of the total number of employees).

Unions have different, but insufficiently reliable, data on the number of their members. The most confident data are those from the research study Union barometer, according to which the level of union organisation has dropped to around $35 \%$ and is showing a tendency towards further falls. ${ }^{19}$

This trend towards a fall in union organisation means, in essence, a fall of trust in unions. This is evidenced in union members leaving and it is also the case that fewer and fewer new employees are becoming members of unions.

The union membership structure has also changed, a factor which is related to the process of privatisation. In Serbia, no matter the numerous weaknesses and conflict that has tracked this process, many companies have been privatised. Analysis confirms the data that, in Serbia in the period from 2001 until the end of 2006, 1852 companies have been privatised, accomplishing a privatisation income amounting to $€ 2.1 \mathrm{bn} .^{20}$

19 Union barometer: Research into employee opinion published by: UGS Nezavisnost Belgrade, 2004, p. 9.

20 Ministry of Finance of the Republic of Serbia Bulletin of public finances No. 5/2005, p. 18. 
We should add that, according to the Law on Privatisation, the deadline for company privatisation where companies that had not been privatised had to be made bankrupt ran out at the beginning of 2007. However, this deadline has been extended via changes made to the Law on Privatisation. It should be added that the over-riding position of experts is that it is only those companies that had no market perspective that have not been privatised.

When we have all this data on the Law on Privatisation in front of us, the position that unions practically do not exist in private companies takes on greater weight. Singular cases of union activities in private companies are more the exception that confirms the rule.

Existing unions are not even trying to enter private companies and form unions there, so as to organise workers to fight for their economic, social and union rights. Furthermore, they are justifying this in terms of the enemy attitude of new owners towards unions. It is clearly the case that most of the new owners (as a rule, with the exception of those foreign owners coming from countries with strong, democratic unions), have a negative attitude towards unions and this, in different ways, discourages or directly prevents the foundation of new unions. In those cases, the country is not doing anything to stop it, or is not sufficiently effective in taking measures as regards the protection of the liberty of union organisation in these companies. However, that in neither case can be any excuse for giving up efforts to organise unions in private companies.

The expected flow of social developments in the time to come, which role anticipates a strengthening of the economic power of private capital and entrepreneurs, directs us to the conclusion that the forming of unions and effective union struggle in private companies will be the biggest attraction to unions. These events will mostly decide the future of unions but also the future position of the members of the world of work in Serbia. In that manner, unions in Serbia are returning to the beginning of the circle from where they started almost two decades ago when they stepped into union pluralism - the struggle for union rights and freedoms, i.e. the real possibility of organising and union action in private companies. The history of one union movement emphatically warns us that this can not be achieved by divided and confronted unions.

Historic experience, as the practice of developed industrial relations confirms, shows that employers and the political powers started essentially to change their relations towards unions, i.e. towards workers' requests, after the organisation and social power of unions had achieved a certain level. This was achieved when unions were able more or less to strike back towards their employers or political governments.

A restoration of the relative balance of forces between the labour world and the capital world was the turning point when industrial relations based in industrial conflict went forward to industrial and social peace. Besides that, we have to bear in mind that unions have not, even in the nowadays economically and technologically developed, democratic European countries or in the rest of the world, permanently rejected radical methods of union struggle such as, for example, public protests, demonstrations and strikes; they just use them less since, in the existing circumstances, it is enough to have a strike threat so that the union is able to achieve its desired goals to protect the working, economic and social rights of their members and employees. Recent happenings in France visibly and clearly confirm that. In any case, we can assert that behind every collective contract or other type of agreement on relations between 
employers, unions and the political powers is the real or potential strength of industrial action.

In that sense, the first test of responsibility and of the real capacities of all the social partners, including unions, to answer the requirements of the modern age and to be responsible, competent actors in developing economic and social reforms in Serbia will be their relationships and, above all, the real capability they hold to build instruments of social peace and social partnership. Also, they have to provide these institutions and instruments with real strength and the social power to accomplish their functions.

As far as threats are concerned, objectively at the centre of attention comes four groups of institutions and social partnership instruments:

- right of employees to information, consultation and co-decision-making

- collective negotiation

- social dialogue

- mechanisms for the peaceful resolution of collective labour disputes.

It obviously reflects the achievements of civilisation and the values of the modern age, when we consider that the state's planning in Serbia had necessarily to take into consideration the following two parameters - international standards; and practice in other countries, above all EU countries. It should be added that the experience of developed democratic countries, primarily EU countries, unequivocally confirms that permanent, systematic and efficient social partnership, and the social peace based upon it, is successfully established when all the above-mentioned mechanisms and institutions are operating as a single functional system.

In that sense, there is a notable need in Serbia to raise to a considerably higher level legal regulations and practice on employee informing, consulting and co-decision-making on the terms of their work and the protection of life and the working environment. This means all of those questions that directly or indirectly influence the quality and dignity of human work.

In this regard, the biggest burden of responsibility is objectively on the side of employers and the political powers. The most important, in that view, is awareness of the need for change towards the collective information, consultation and co-decisionmaking of employees in the light of creating a positive atmosphere in the company; encouraging a healthy game between employees; developing feelings of attachment and responsibility for the destiny of the company; seeking the inclusion of creative energy and the incorporation of the knowledge and experience of each individual in the working process and the advancement of technology and organisation behind working conditions - i.e. things that ultimately place a positive mirror on the company's management and profitability. It also includes the accomplishment of the interests of employers, employees and the political powers. Of course, in condition analysis and the search for a routemap to advance these issues, it is necessary to bear in mind that informing, consulting and co-decision-making are, in essence, three mutually connected and conditional steps in the one process. ${ }^{21}$

Rights to information, consultation and co-decision-making represent a very successful method of motivating employees, as well as being a managerial instrument

21 Bronco Lubarda (1999) Industrial relations lexicon Labour Press: Belgrade, p. 73. 
that encourages higher efficiency, productivity and the concurrency of modern companies. Modern managers are conscious that only satisfied and motivated personnel can guarantee good results in today's global market.

Companies in Serbia that are still in the transition process in most cases miss the personalisation of resources in the light of new technologies, but there are serious problems within the domain of decent human resource management.

Human resource management is a very young discipline in Serbia whose significance and role is noticed by the whole economy: micro, small and large companies alike. New trends in human resource management, knowledge societies, the lifelong studying model and the promotion of a society based upon innovations clearly speaks of a change in consciousness among domestic companies that increasingly admit that the human factor is the key to their growth on the market.

Furthermore, the trends set by companies every day in Serbia refer also to that, especially the large corporations who are putting human resource development at the forefront, while many others are incorporating it and forming their own policies since that represents the framework for their growth in regard to accomplishing new markets and new buyers.

In companies in Serbia which should have motivated and qualified human resources, there should be implanted the best practice policy of developed European countries or the 'Asian tigers', which is to provide employees with good conditions for education, internal and external communications with which to manifest their concerns and opportunities for employees at all levels to show their professional creativity.

Bearing in mind the current situation, very rare are those companies that successfully manage human resources and fulfil certain European standards in that regard. For that situation, the blame should be take by employers and managers but also by the country as the third social partner whose role is to create a qualitative economic ambience that will define the development of an entrepreneurial society and a society based upon knowledge. In that sense, there is a great need to promote a system of lifelong study and the reality of the functioning of a commercial market, that there is no more job stability and that it is completely normal, even desirable, to change workplaces and companies.

In order that the labour market functions well, it is necessary to implement a model based on flexible employment and greater labour mobility. In this respect, it is necessary to have one comprehensive and consistent state policy, as well as a national strategy for economic development that would be realisable in practice, with real aims and fully compatible with other strategies (jobs, development, MSP sector, even regional development, etc.).

Within a perception of the specifics of Serbia, one institution needs to be specially extricated that has, in practice, been almost completely forgotten about: the Council for Personnel. The Council for Personnel is, in any case, part of a generally known civilisation heritage, as well as being a very strong and efficient instrument of social democracy in which employees and their unions accomplish a strong influence on corporate company policy. Such an analysis is undoubtedly confirmed by the experiences of Germany, France, Italy and the Scandinavian countries. The significance and role for a council for personnel on industrial democracy, as for the entire democratic 
process across society, was written about, almost one century ago, by Antonio Gramsci, thus proving its democratic and human sense.

In addition, the Constitution of Serbia provides a constitutional base, as do ILO Conventions and the European Social Charter, while the Law on Work foresees the possibility of founding an employee trust, but this significant legal possibility is almost not used at all since only a small number of workers and union activists knows of the possibility of its existence. This is, significantly, the consequence of a negative heritage from the time of self-management. However, this does not bring into question the need for employee and union influence on the creation and following through of company policy, whether or not there is such a trust or employee council.

\section{Conclusion}

Serbia has still not stepped out from the spellbound circle of the first, most contradictory and most conflict-ridden phase of transition. The most recent data also confirm that in Serbia around fifty strikes are organised daily. Such fifty points of neuralgia undoubtedly leave a painful mark on management and personnel, as well as on the range of economic activity across all levels, national, regional and local. By its live effects, the key actor in all these conflicts that, with a changeable level of intensity, permanently disturbs our society is the world of labour.

But that, on the whole unfavourable, position of the world of labour is, at the same time, an indicator of the limited scope of economic and social reform processes, as well as being the obstacle to a more dynamic and successful transition flow. This reminds us of the well-known truth that a democratic, developed, human society can not be built on the poverty of the majority. On the contrary, Serbia threatens the danger of living the destiny of one of any number of Latin American countries as regards the danger of a long stabilisation of poverty, with a partition of society between a minority that is extremely rich and a majority that is poor, just at different levels of poverty. Research studies into public opinion carried out in the previous year strongly warn us that, for a majority of citizens who are members of the world of labour, there is a dominant feeling of fear for the loss of their jobs, distrust in the political powers, discontent with their own material and social position and an inexistence of hope in a real future. Experience of the world we live in, including that of successful transition countries, confirms the existence of just one way in which this can be prevented - the question of human resources needs to be put at the centre of attention of all actors in the political and social life of Serbia. In addition, the quality of life of ordinary people should be taken as a basic parameter of success for the political powers and the representatives of employers and employees, as relevant factors in the socio-economic development process of the country.

\section{References}

Arandarenko, Mihail (2005) 'Elements of employment strategy' collection from Consultation DEB: 'Unemployment in Serbia - problem and alternatives' Economic views Belgrade: 26.

Dašić, David (2001) Market economy European University for International Management and Business, Belgrade: 217. 
Dukić, Petar (2006) 'The organised world of labour in Serbia today: between economic reforms and populism' South-East Europe Review for Labour and Social Affairs 9(4): 20.

Franićević, V and I. Bićanić (2003) 'The poor, excluded and transitional losers in south-east European countries: Explaining the paradox' draft paper for the International Conference on Inequality, poverty and social expansion in south-east Europe Friedrich-Ebert-Stiftung: Belgrade, p. 27.

Grindt, Keith (2002) The sociology of work Polity Press: Cambridge: 158.

Kastratović, Edita (2008): Even regional development and MSP sector in Serbia International Higher School for Entrepreneurs: Belgrade.

Lubarda, Branka (1999) Industrial relations lexicon Labour Press: Belgrade.

Mihajlović, Srećko, Zoran Stojiljković and Gradimir Ivanić (2004) Union in changes - changes in union UGS Nezavisnost and Progetto Sviluppo, CGIL: Belgrade, p. 36.

Mijatović, Jugoslav (2005) "Joblessness problems in Serbia in the period of transition and possibilities for solving them' Economy views DEB: Belgrade, II, p. 63.

Ministry of Finance of the Republic of Serbia Bulletin of public finances No. 5/2005, p. 18.

National strategy in the fight against poverty Document of the Government of the Republic of Serbia, Belgrade, 2003, p. 2.

RZS - Publication of employment in Serbia, Belgrade, 2006, p. 11.

RZS Notice No. 59, Belgrade, 2007, p. 2.

Šever, Bude (2005) 'Causes of unemployment' collection from DEB Council: Unemployment in Serbia - Problems and alternatives DEB: Belgrade, p. 145.

Šram, Zlatko (2006) 'Social attitudes and individual qualities as political culture components' in the collection Five years of transition in Serbia Friedrich-Ebert-Stiftung, SD Club: Belgrade: 201.

Stajić, Dubravka (2002) Burdensome transition Institute for political studies, Belgrade: 127 . 